\title{
Long-term effects of changing atmospheric pollution on throughfall, bulk deposition and streamwaters in a Mediterranean forest
}

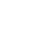

(1)

Laura Aguillaume ${ }^{1}$, Anselm Rodrigo ${ }^{1,2}$, Anna Avila ${ }^{1,2^{*}}$

(1)

${ }^{1}$ CREAF, Cerdanyola del Vallès 08193, Spain.

${ }^{2}$ Universitat Autònoma de Barcelona, Cerdanyola del Vallès 08193, Spain.

*Corresponding author, Anna Avila: anna.avila@uab.cat; Tel: 935814669 ; Fax: +34935814151

Laura Aguillaume: aguillaume.laura@gmail.com

Anselm Rodrigo: anselm.rodrigo@uab.cat

This is the author's version of a work that was accepted for publication in Science of the total environment (Ed. Elsevier). Changes resulting from the publishing process, such as peer review, editing, corrections, structural formatting, and other quality control mechanisms may not be reflected in this document. Changes may have been made to this work since it was submitted for publication. A definitive version was subsequently published in Aguillaume, L., Rodrigo A. and Àvila, A. "Long-term effects of changing atmospheric pollution on throughfall, bulk deposition and streamwaters in a Mediterranean forest" in Science of the total environment, vol. 544 (Feb. 2016), p. 919928. DOI 10.1016/j.scitotenv.2015.12.017" 
The abatement programs implanted in Europe to reduce $\mathrm{SO}_{2}, \mathrm{NO}_{2}$ and $\mathrm{NH}_{3}$ emissions are here evaluated by analysing the relationships between emissions in Spain and neighbouring countries and atmospheric deposition in a Mediterranean forest in the Montseny Mountains (NE Spain) for the last 3 decades. A canopy budget model was applied to throughfall data measured during a period of high emissions (1995-1996) and a period of lower emissions (2011-2013) to estimate the changes in dry deposition over this time span.

Emissions of $\mathrm{SO}_{2}$ in Spain strongly decreased (77\%) and that was reflected in reductions for $\mathrm{nsSSO}_{4}{ }^{2-}$ in precipitation (65\% for concentrations and $62 \%$ for $\mathrm{SO}_{4}{ }^{2}-\mathrm{S}$ deposition). $\mathrm{A}$ lower decline was found for dry deposition (29\%).

Spanish $\mathrm{NO}_{2}$ emissions increased from 1980 to 1991, remained constant until 2005, and decreased thereafter, a pattern that was paralleled by $\mathrm{NO}_{3}{ }^{-}$concentrations in bulk precipitation at Montseny. This pattern seems to be related to a higher share of renewable energies in electricity generation in Spain in recent years. However, dry deposition increased markedly between 1995 and 2012, from 1.3 to $6.7 \mathrm{~kg} \mathrm{ha}^{-1} \mathrm{y}^{-1}$. Differences in meteorology between periods may have had a role, since the recent period was drier thus probably favouring dry deposition.

Spanish $\mathrm{NH}_{3}$ emissions increased by $13 \%$ between 1980 and 2012 in Spain but $\mathrm{NH}_{4}{ }^{+}$ concentrations in precipitation and $\mathrm{NH}_{4}{ }^{+}-\mathrm{N}$ deposition showed a decreasing trend $(15 \%$ reduction) at Montseny, probably linked to the reduction ammonium sulphate and nitrate aerosols to be scavenged by rainfall. $\mathrm{NH}_{4}{ }^{+}-\mathrm{N}$ dry deposition was similar between the compared periods.

The $\mathrm{N}$ load at Montseny (15-17 $\left.\mathrm{kg} \mathrm{ha}^{-1} \mathrm{yr}^{-1}\right)$ was within the critical load range proposed for Mediterranean sclerophyllous forests (15-17.5 $\mathrm{kg} \mathrm{ha}^{-1} \mathrm{yr}^{-1}$ ). The onset of $\mathrm{N}$ saturation is suggested by the observed increasing $\mathrm{N}$ export in streamwaters.

Key-words: Emission reductions, Atmospheric deposition, Nitrogen, Sulfate, Throughfall, Canopy. 
High atmospheric deposition of sulphur $(\mathrm{S})$ and nitrogen $(\mathrm{N})$ in the last century has lead to the acidification and eutrophication of many terrestrial ecosystems in Europe and North America, peaking in the 1970-1980 (Aber et al., 1998; EC, 2001; Reuss and Johnson, 1986). To counteract these adverse effects, transboundary amendment programs were launched by the Convention on Long-Range Transboundary Air Pollution (CLRTAP) in the frame of the United Nations Economic Commission for Europe (UNECE, 2011). Upon the implementation of national emission limits, significant declines were observed since the mid 1980s in $\mathrm{SO}_{2}$ emissions and $\mathrm{S}$ in precipitation in Europe (Tørseth et al., 2012). Nitrogen emissions were also significantly reduced in many European countries, although higher variability was found among regions and the changes were different for oxidized or reduced N (Fagerli and Aas, 2008; Konovalov et al., 2008; Lövblad et al., 2004). A summary of the major results following the implementation of pollution control measures can be found in Grennfelt and Hov (2005). Concerning Spain, $\mathrm{SO}_{2}$ emissions were readily cut, but the country still exceeded in 2012 the $\mathrm{NO}_{\mathrm{x}}$ and $\mathrm{NH}_{3}$ emissions ceilings for 2010, established at 847 and $353 \mathrm{Gg}$ respectively (EC, 2001). The link between emissions, air concentrations and deposition is complex because of the interplay of the meteorological conditions, the chemical interaction between pollutants in the atmosphere and the spatial scale of the region of influence. In this sense nonlinearities have been found between emission reductions and the decline in rainwater concentration (Fowler et al., 2007).

Dry deposition of airborne pollutants makes also a significant contribution to the atmospheric load of most ecosystems. However, long time records of changes in dry deposition for the last decades are scarce. Changes in dry deposition have also been found to change non-linearly with emissions (Fowler et al. 2005). This has been attributed to the fact that for $\mathrm{SO}_{2}$, the deposition velocity $\left(\mathrm{V}_{\mathrm{d}}\right)$ is controlled by the $\mathrm{NH}_{3} / \mathrm{SO}_{2}$ ratio, where $\mathrm{SO}_{2}$ deposition increases as leaf $\mathrm{pH}$ raises in response to $\mathrm{NH}_{3}$ deposition (Erisman et al., 1998; Fowler et al., 2001). Thus, dry deposition will not only depend on $\mathrm{SO}_{2}$ concentrations, but also on its relative abundance respect to $\mathrm{NH}_{3}$. Also, declining air $\mathrm{SO}_{2}$ concentrations will affect the partitioning of gaseous $\mathrm{NH}_{3}$ and 
particulate $\mathrm{NH}_{4}{ }^{+}$, which in turn will affect the spatial range affecting deposition, since $\mathrm{NH}_{3}$ will tend to be locally deposited while fine-sized $\mathrm{NH}_{4}{ }^{+}$-sulfate aerosols have a longer residence time in the atmosphere and will be mostly transported to longer distances (van Jaarsveld et al., 2000).

Throughfall (TF), the water flux collected under the forest canopy, has been widely used to provide an estimation of dry deposition (De Vries et al., 2003; Lindberg and Lovett, 1992). However, throughfall does not truly represent total deposition, since it also is affected by chemical exchanges at the canopy level (Parker, 1983). When using throughfall measurements to derive dry deposition fluxes, a distinction has to be made between dry deposition and canopy exchange processes. These include the leaching of elements from internal plant pools and/or the uptake by the canopy of gases or dissolved solutes (Lovett and Lindberg, 1984; Schaefer and Reiners, 1990). To sort this out, a canopy budget model has been widely used (Draaijers and Erisman, 1995; Staelens et al., 2008) and will be here applied to estimate dry deposition from throughfall measurements.

The Iberian Peninsula, in the south-western corner of the European continent, is influenced by air masses from contrasting provenances. Five main air mass movements have been established based on the frequency of back trajectories: 1) European or continental, 2) from the Atlantic Ocean, 3) from North Africa, 4) from the Mediterranean, 5) from shorter pathways, as recirculating air masses over the Iberian Peninsula (Calvo et al., 2012; Escudero et al., 2007; Izquierdo et al., 2012). A cluster classification of daily back-trajectories for the periods 1984-1993 and 1998-2009 indicated that the most frequent air flows at the Montseny mountains in NE Spain were from the Atlantic Ocean (39 and 31\% for the two study periods) and the Peninsular recirculation (27-25\%). Thus, the major air pollution influence at the north-east coast of Spain may be from emissions from the Iberian Peninsula itself. However, during winter, a good correlation was observed between air masses from the Mediterranean and $\mathrm{NO}_{3}{ }^{-}$ deposition (Izquierdo et al., 2014). Also, source receptor models indicated the influence of emissions from eastern provenances on the rain chemical composition in NE Spain (Izquierdo et al., 2012). 
117 The aim of this work is to examine the relationships between $\mathrm{S}$ and $\mathrm{N}$ emissions in Spain 118 and neighbouring countries from the early 1980s to 2014 and rain concentrations and deposition at a site in the NE of the Iberian Peninsula, in order to check whether the abatement measures implemented by CLRTAP protocols are reflected in reduced deposition. This has been undertaken by comparing the evolution of bulk deposition trends at a rural forested site (La Castanya, Montseny) in NE Spain and the evolution of emissions in the Iberian Peninsula, France, Italy and the totals for the European Union (EU28) for this period. Previous studies have documented a $\mathrm{SO}_{4}{ }^{2-}$ decrease in bulk deposition in NE Spain (Avila, 1996; Avila and Rodà, 2002); here we expand these studies for a longer time series and incorporate the examination of changes in dry deposition. Changes in dry deposition along the last 3 decades cannot be traced in NE Spain because of the lack of a continuous monitoring scheme for dry deposition. However, throughfall measurements in two contrasting periods over this time span (in 1995-1996, a period of high emissions and in 2011-2013, a period of lower emissions) can provide and insight on dry deposition changes, particularly for $\mathrm{S}$.

Several studies have reported changes in surface stream water chemistry after reduction of pollutant emissions in temperate forests in central and north Europe and North America (Driscoll et al., 1998; Evans et al., 2007; Skjelkvåle et al., 2005). This paper also tackles this issue by exploring the response at the ecosystem level of emissions reductions, by studying changes in streamwater chemistry for a stream draining an undisturbed forested catchment representing a typical Mediterranean forest.

\section{Material and methods}

\subsection{Study site}

143 The study site was located in La Castanya valley (LC, $41^{\circ} \div 6^{\prime} \mathrm{N}, 2^{\circ} 2^{\prime} 21^{\prime} \mathrm{E}, 700$ m.a.s.I), within the Montseny mountains (Fig.1) about 40km NNE from Barcelona and 25km from the 
146 (Quercus ilex L.). Forests at La Castanya valley were exploited in the past for charcoal 147 production, but these activities were abandoned about 60 years ago and the forest is 148 increasing in biomass (Rodà et al., 1999).The upper part of La Castanya valley comprises a belt of beech forest at 1100-1200m, while heathlands and grasslands extend above this altitude up to $1350 \mathrm{~m}$. Dominant lithology is metamorphic schist and phyllite. Soils are shallow with an organic layer $0-5 \mathrm{~cm}$ deep and an average total depth of $60 \mathrm{~cm}$ (Hereter and Sánchez, 1999). Soils are classified as Entisols or Inceptisols (Soil Survey Staff 1992).

Climate is meso-Mediterranean sub-humid, with a clear seasonal cycle of higher precipitation in spring and summer. Variability among years is very high (Fig. 2). At the LC station, mean precipitation from 1983 to 2014 was $862 \mathrm{~mm} \mathrm{y}^{-1}$ (range from 518 to $1601 \mathrm{~mm} \mathrm{y}^{-1}$; Fig. 2) and mean air temperature 9.5으.

This site is considered as a rural background station that is topographically sheltered to some extent from air pollution from the Barcelona metropolitan area. However, during the warm half of the year diurnal sea-land breezes carry pollution from the coast and lowland plains to the upper Montseny slopes, where LC lies, by midday (Pérez et al., 2008).Besides, long-range pollutant transport also influences atmospheric deposition at this site (Izquierdo et al., 2012).

Stream discharge was recorded in a stream named Torrent de la Mina (TMO) which is gauged with a 120 V-notch weir. This catchment has a surface of 205 ha and comprises two distinct zones: an upper plateau with grassland and heathlands ( $30 \%$ of the catchment) and holm-oak forests covering the steep slopes that conform the rest of the catchment (Fig 1).

\subsection{Field sampling}

Open field measurements

171 Weekly bulk deposition samples were obtained from August 1983 to August 2014

172 (interrupted from September 2000 to March 2002). Wet-only deposition (ESM 173 Andersen instruments) was sampled in parallel to bulk deposition during 2008-2013 but because of the longer bulk deposition record, we will deal here with bulk deposition 
175 data for the comparison of emissions and deposition trends. Bulk/wet deposition collectors, a rain tipping bucket gauge and a meteorological station (Campbell with

177 CR1000 data logger) were located at a clearing in the forest close to the throughfall plots (Open field sites, Fig. 1). The open field measurements were located at site LC1 since August 1983 to September 2000. Since March 2002, they were located at site LC2 (Fig. 1), about $850 \mathrm{~m}$ distant from the first site. Bulk collectors consisted on 19-cmdiameter funnels connected by a looping tygon tube to a $10-\mathrm{L}$ polyethylene bottle for the period 1983-2010. In 2011, NILU-type (Norwegian Institute for Air Research) funnels were used and a plastic membrane was fitted in the funnels neck which connected to a 2-L polyethylene bottle. Funnels were directly connected to the bottles, which were kept in the dark to avoid the growth of microorganisms. Four (1983-1996) and two (1997-2014) replicate collectors were used.

\section{Throughfall measurements}

The throughfall chemistry was sampled in two periods separated by a 15 -year span: the first one, in 1995-1996, took place during a period of still high emissions in Spain while the second one, in 2011-2013, corresponded to a period of much lower emissions. To characterize the throughfall chemistry in the first period we used throughfall data measured in two plots in Montseny from June 1995 to June 1996 (Table 1). One plot was located at La Castanya valley facing to the north (LC1, Fig 1). The second plot was at Riera de Sant Pere (RP1) $8 \mathrm{~km}$ apart from La Castanya, in the Montseny slopes that face to SW and had a similar aspect to that of the LC2 throughfall plot. It was considered that the averaged throughfall composition of RP1 and LC1 better represented the canopy changes on incident precipitation in the early period. Throughfall collectors in this period consisted of a $10-\mathrm{cm}$ funnel connected to a $2-\mathrm{L}$ bottle, kept in the dark (Rodrigo et al., 2003). Throughfall in the period March 2011-March 2013, was sampled in location LC2, using 12 collectors of NILU-funnel type. Details on the forest structure of the 3 throughfall sampling sites are given in Table 1. Although differences in location will introduce uncontrolled spatial variation in throughfall measurements, the plots had a similar forest structure: they formed a continuous closed monospecific canopy of holmoak submitted to similar climate, although the difference in aspect may have some effect. A review of the rainfall partitioning by vegetation in Mediterranean conditions 
has shown that the forest structural parameters that mostly influence throughfall are age, height, diameter at breast height (DBH) and basal area (Llorens and Domingo, 2007). Differences in some of these variables between the plots were small (Table 1) and probably within the error of regressions provided by Llorens and Domingo (2007). Further details on throughfall field sampling can be found in Rodrigo et al. (2003) and Aguillaume (2015).

For bulk deposition and throughfall, volume weighted mean (VWM) concentrations were calculated based on weekly samples weighted by weekly precipitation volume. The corresponding fluxes were obtained by multiplying annual VWMs by annual precipitation/throughfall volume and are expressed as $\mathrm{kg} \mathrm{ha}^{-1} \mathrm{y}^{-1}$, except for $\mathrm{H}^{+}$and alkalinity, in eq $\mathrm{ha}^{-1} \mathrm{y}^{-1}$.

Non sea salt sulphate (nss $\mathrm{SO}_{4}{ }^{2-}$ ) concentrations in bulk deposition (BD) were calculated as:

$\mathrm{nSS} \mathrm{SO}{ }_{4}{ }^{2-}{ }_{\mathrm{BD}}=\mathrm{SO}_{4}{ }^{2-}{ }_{\mathrm{BD}}-\left(\mathrm{Na}^{+}{ }_{\mathrm{BD}} * 0.12\right)$,

where $\mathrm{SO}_{4}{ }^{2-}{ }_{\text {sea salt }} / \mathrm{Na}^{+}{ }_{\text {sea salt }}=0.12 \quad($ Drever, 1982)

\section{Streamwater measurements}

Streamwater was collected from a stream draining a 200 ha catchment named Torrent de la Mina (TMO) within the La Castanya valley (Fig. 1). The recording period for discharge and streamwater chemistry comprised an initial (1990 to 1999) and a recent period (2010 to 2014). Water level was measured with an OTT ${ }^{\mathrm{TM}}$ water level recorder in the initial period and with a pressure probe (Schlumburger Water Services) in the recent one. Annual discharge ranged between 150 and $888 \mathrm{~mm} \mathrm{y}^{-1}$ (Fig. 2).

Grab samples of stream water were collected with an approximate weekly schedule from a sampling point upstream from the stilling pond. They were collected in highdensity polyethylene $250-\mathrm{mL}$ bottles after a previous triple rinse with stream water.

We calculated annual VWM for bulk precipitation and stream waters, expressed in $\mu$ eq $\mathrm{L}^{-1}$ for hydrological water years defined from 1 September. For throughfall, a more 
restricted data record obliged to consider different annual periods (June 1995 to June 1996 in the initial and March 2011 to March 2013 for the recent period).

For the stream waters, we first calculated annual fluxes $\left(F\right.$, in $\left.\mathrm{kg} \mathrm{ha}^{-1} \mathrm{y}^{-1}\right)$ by:

$\mathrm{F}=\sum_{i=1}^{N} \mathrm{C}\left(\mathrm{t}_{\mathrm{i}}\right) * Q\left[T_{i}\right]$

Where $C\left(t_{i}\right)$ is the instantaneous concentration of the studied elements at time $t_{i}$ (in $\mathrm{mg}$ $L^{-1}$ ) and $Q\left[T_{i}\right]$ is the discharge (in $L$ ) for the period $T_{i}=\left(\tau_{i}-\tau_{i-1}\right)$, with $\tau_{i-1}<t_{i}<\tau_{i}$, and $N$ is the number of samples taken during the whole year. To give the annual VWM concentrations, fluxes were divided by the accumulated stream discharge for the year.

Several works have attempted to determine the best unbiased estimate of flowweighted solute concentrations and fluxes, since the appropriateness of the estimate depends on the frequency of sampling related to the duration of stormflows (Rekolainen et al., 1991; Stone et al., 2000; Swistock et al., 1997). Calculations based on weekly sampling and the water flow corresponding to each one of the samples, the procedure used here, have been recommended as a compromise between the effort of sampling and the accuracy of the estimate. The accuracy of estimates with this procedure has been found to lie within $10 \%$ of expected values (Rekolainen et al., 1991; Stone et al., 2000; Swistock et al., 1997).

\subsection{Chemical analyses}

Samples were taken to the laboratory and were analyzed for $\mathrm{pH}$, conductivity and alkalinity within $24-48 \mathrm{~h}$ from sampling. Samples were filtered with $0.45 \mu \mathrm{m}$ size pore acetate cellulose membrane filters and $60-\mathrm{mL}$ aliquots were frozen until analysis. Concentrations of $\mathrm{Na}^{+}, \mathrm{K}^{+}, \mathrm{Mg}^{2+}, \mathrm{Ca}^{2+}, \mathrm{NH}_{4}^{+}, \mathrm{Cl}^{-}, \mathrm{NO}_{3}{ }^{-}$and $\mathrm{SO}_{4}{ }^{2-}$ were measured by ion chromatography (Dionex, Sunnyvale, USA). Data quality was checked with the inclusion of synthetic samples of known ionic concentrations during analytical runs. The quality of the analytical data was checked by a: 1) conductivity index (ratio of measured conductivity to conductivity calculated from the concentration of all measured ions and their specific conductivities), 2) an ionic index (ratio of the sum of cations to the sum of 
anions). For bulk and wet deposition, a $20 \%$ variation about the central index value (1.00) was accepted, according to the ICP-Forest manual (ICP-Forest Manual, 1998). Because TF contains weak acids that may not have been included in our alkalinity measurements, we did not impose the $20 \%$ restriction about the central value to throughfall ionic index checks. Further analytical checks were undertaken by participating in international comparisons (AQUACON Med-Bas, Mosello et al., 1998), with highly satisfactory results.

\subsection{Canopy budget method}

To separate canopy exchange from dry deposition, a Canopy Budget Model (CBM) has been generally used ( Draaijers and Erisman, 1995; Staelens et al., 2008; Adriaenssens et al., 2012). The CBM is based on the following balance between fluxes above and below the canopy: TF+SF = PD + DD + CE, where TF stands for throughfall, SF for stemflow, PD for Precipitation Deposition, DD for Dry Deposition and CE for Canopy Exchange. Canopy exchange, if positive, indicates the leaching of ions from the canopy $(C L)$, and if negative, the uptake of ions (CU). Stemflow at the LC site contributed only $3 \%$ of total rainfall (Rodrigo et al., 2003) and because of its small contribution, SF fluxes have not been considered here. Then,

$\mathrm{TF}-\mathrm{PD}=$ net $\mathrm{TF}=\mathrm{DD}+\mathrm{CE}$

In this procedure, dry deposition is estimated based on a tracer ion that is assumed not to be influenced by canopy exchange processes and assuming that aerosols containing the other ions of interest have a similar deposition behaviour than the ion chosen as reference (Ulrich, 1983). Here $\mathrm{Na}^{+}$was used as an inert tracer as recommended in several studies (Staelens et al., 2008) to derive DD for base cations, $\mathrm{SO}_{4}{ }^{2-}$ and $\mathrm{Cl}^{-}$. To characterise PD, either wet or bulk deposition can be used, but using wet deposition will result in the estimation of fine plus coarse aerosol dry deposition, while bulk deposition would mostly indicate dry deposition of fine aerosols (Balestrini et al., 2007); thus wet deposition is used here.

Nitrogen compounds can be taken up in the canopy (Boyce et al., 1996; Ignatova and Dambrine, 2000) and there is a need to estimate this flux in order to derive dry 
deposition. To estimate nitrogen canopy uptake (CU), we considered that $\mathrm{NH}_{4}{ }^{+}$uptake can be equated to the net leaching of base cations, and $\mathrm{NO}_{3}{ }^{-}$is considered to be retained at a fixed efficiency rate related to $\mathrm{NH}_{4}{ }^{+}$. To balance the charges, $\mathrm{NO}_{3}{ }^{-}$uptake is then equated to $\mathrm{H}^{+}$uptake (Staelens et al., 2008; Adriaenssens et al., 2012). It is well known that $\mathrm{NH}_{4}{ }^{+}$is preferentially retained by leaves relative to $\mathrm{NO}_{3}{ }^{-}$and an efficiency factor of 6 for $\mathrm{NH}_{4}{ }^{+}$vs $\mathrm{NO}_{3}{ }_{3}^{-}$uptake has been proposed for forests in Europe (de Vries et al., 2003; Schmitt et al., 2005; Thimonier et al., 2005; Zhang et al., 2006) and will be also applied here:

$$
C U(\mathrm{NH} 4+\mathrm{NO} 3)=\left(\frac{x N H 4 *(T F) \mathrm{NH} 4+(T F) \mathrm{NO} 3}{x N H 4 *(T F) \mathrm{NH} 4}\right) * C U(\mathrm{NH} 4)
$$

with $\mathrm{x}=6$.

\subsection{Statistical analysis}

Air pollution emissions per country were obtained from the EMEP database site: http://www.ceip.at/ms/ceip home1/ceip home/webdab_emepdatabase/reported emissiondata/).

Local urban $\mathrm{NO}_{\mathrm{x}}$ air concentration data was obtained from the Catalan Air Quality network for Barcelona (Gràcia station; Direcció General de QualitatAmbiental, Generalitat de Catalunya). Data from electricity generation in Spain were downloaded from Red Eléctrica Española (http://ree.es/es/publicaciones).

Mann-Kendall test were used to analyze trends in emissions for the years reported by EMEP (1980-2012), and for bulk deposition measured at Montseny (1983-2014). Sen's slope estimator was used to indicate the rate of change, a robust method for estimating the true slope of a linear trend (Gilbert, 1987). Stream water concentration and fluxes presented a non-continuous record which prevented using the Mann-Kendall tests, thus differences between an initial (1990-1999) and recent period (2010-2014) were tested with ANOVA tests. Percent changes for emissions and bulk deposition were also recalculated for the same years of streamwater data for a more accurate comparison. Stepwise regressions were used to determine principal contributors to $\mathrm{N}$ and $\mathrm{S}$ rain concentrations and deposition at Montseny. 


\section{Results}

\subsection{Changes in emissions}

The evolution of emissions in Spain and its neighbouring countries can be seen in Fig. 3. The significance of the trends was checked with the Mann-Kendall test and percent reductions or increases were calculated comparing 5-year averages at the beginning and the end of the reported periods. The significance of the Mann-Kendall Tau, and the \% difference between the 5-yr initial and recent period are shown in Table 2.

Sulfur dioxide reductions were similar in all countries, decreasing between 75 and $85 \%$. For $\mathrm{NO}_{2}$, Italy and France accomplished higher reductions (51 and 42\% respectively) than Spain and Portugal (34 and 32\%). In all countries except Spain, the Mann-Kendall Tau was significant for $\mathrm{NO}_{2}$ (Table 2). The evolution of emissions in France and Italy showed a change of trend in the early 1990s with a clear declining evolution thereafter (Fig 2). For Spain, there was an increasing trend until the early 1990s, emissions remained stable at high levels until around 2005, and since 2006 a sharp declining trend was initiated (Fig 3).

For $\mathrm{NH}_{3}$, Spain and France increased emissions by $13 \%$ and $1 \%$, respectively, while $\mathrm{NH}_{3}$ emission declined in Italy and Portugal (Table 2).

\subsection{Relationship of rain and throughfall chemistry with emissions}

Rain concentrations are strongly influenced by precipitation amounts. The time trend of annual precipitation did not show a significant pattern during the study period (Fig. 2). Hence, trends in element concentrations in precipitation, though partly influenced by the variability of the rainfall amount, were probably more influenced by atmospheric emission and transport processes.

The temporal evolution of $\mathrm{SO}_{4}{ }^{2-}, \mathrm{NO}_{3}{ }^{-}$, and $\mathrm{NH}_{4}{ }^{+} \mathrm{VWM}$ concentrations in bulk deposition at Montseny are compared to $\mathrm{SO}_{2}, \mathrm{NO}_{2}$, and $\mathrm{NH}_{3}$, Spanish emissions in Figs. $4 \mathrm{a}, \mathrm{b}$ and $\mathrm{c}$, respectively. Pearson regression analysis indicated that $\mathrm{SO}_{4}{ }^{2-} \mathrm{VWM}$ concentrations were strongly correlated with the Iberian Peninsula (sum of Portuguese and Spanish) $\mathrm{SO}_{2}$ emissions (Pearson $\mathrm{R}=0.85 ; \mathrm{p}<0.0001$ ), with France and Italy emissions (both $\mathrm{R}=0.82$ 
$347 \mathrm{p}<0.0001)$ and with the EU28 emissions as a whole $(R=0.65 ; p=0.0002) . \mathrm{SO}_{4}{ }^{2-}-\mathrm{S}$ 348 deposition fluxes at Montseny were also highly correlated with emissions (Pearson R 349 significant to $p<0.001$ for the Iberian Peninsula, France, Italy and the EU28). Thus, the 350 effective widespread measures undertaken in Europe since the early 1980 to reduce $\mathrm{SO}_{2}$ emissions have been translated into a reduction in precipitation $\mathrm{SO}_{4}{ }^{2-}$ concentrations and $\mathrm{S}$ deposition fluxes. However, the rate of reduction was not proportional: while $\mathrm{SO}_{2}$ emissions were reduced around $80 \%$ (Table 2), $\mathrm{SO}_{4}{ }^{2-}$ concentrations and $\mathrm{S}$ fluxes were only reduced by 55-63\% when comparing the values in 1995-1996 to those in 2011-2013 (Tables 3 and 4).

The evolution of $\mathrm{NO}_{2}$ Spanish emissions from 1980 to 2014 showed different phases: an increase from 1980 to 1991 , a plateau around $1400 \mathrm{Gg} \mathrm{NO}_{2}$ from 1992 to 2005, and a decrease thereafter (Fig 4b). However, when breaking the series considering 2005 as a tipping year, a significant increase occurred in the first period $(p<0.001$; Sen slope $=17.9$ $\left.G g y^{-1}\right)$, and a significant decrease from 2005 on $\left(p=0.003\right.$, Sen slope $\left.=-78 G g ~ y^{-1}\right)$. Similarly, nitrate VWM in bulk precipitation at Montseny increased until 2005 and decreased thereafter, being significantly correlated with the Iberian Peninsula $\mathrm{NO}_{2}$ emissions (Pearson $\mathrm{R}=0.66 ; \mathrm{p}<0.0001$ ), but not correlated to France, Italy or the EU28 $\mathrm{NO}_{2}$ emissions ( $p>0.05$ ). Mann-Kendall trend test indicated a significant increasing trend until $2005\left(p=0.001\right.$, Sen slope $=0.51 \mu$ eq $\left.\mathrm{L}^{-1} \mathrm{y}^{-1}\right)$, and a decrease for the second period $(p=0.019)$ at a rate of $-1.65 \mu$ eq $\mathrm{L}^{-1} \mathrm{y}^{-1}$ (Fig. 4b). When considering emissions for the whole EMEP record (1980 to 2012), neither $\mathrm{NO}_{2}$ emissions nor $\mathrm{NO}_{3}{ }^{-}$-concentrations showed a significant pattern ( $p=0.26$ and 0.18 , respectively).

No significant correlation was found between $\mathrm{NO}_{3}{ }^{-}-\mathrm{N}$ fluxes at Montseny and emissions, except for Spanish $\mathrm{NO}_{2}$ emissions ( $\left.p=0.014\right)$.

The relevance of the different contributions to $\mathrm{NO}_{3}{ }^{-} \mathrm{VWM}$ concentrations was tested with a stepwise regression considering $\mathrm{NO}_{2}$ emission data from EMEP (France, Italy, the Iberian Peninsula and the EU28) and a proxy of local emissions (near-ground $\mathrm{NO}_{\mathrm{x}}$ air concentrations in the center of Barcelona from the Catalan Air Quality network) as independent variables. Precipitation amount was also included due to the marked dilution effect of rain on $\mathrm{N}$ concentrations (Prado-Fiedler, 1990). The model included 
377 precipitation (standardized coefficient $\mathrm{B}=-0.31 ; \mathrm{p}=0.012$ ); $\mathrm{NO}_{\mathrm{x}}$ Barcelona emissions $(\mathrm{B}=$ 378 0.42; $p=0.005)$ and Iberian Peninsula emissions ( $B=0.43 ; p=0.011)$. Correlation 379 coefficient for this model was $r=0.92$. Thus, both local and national emissions strongly affect $\mathrm{NO}_{3}{ }^{-}$deposition in Montseny.

381

Spanish $\mathrm{NH}_{3}$ emissions significantly increased between 1980 and 2012 (Table 2), but $\mathrm{NH}_{4}{ }^{+}$concentrations in bulk deposition did not show a significant temporal trend in this period $(p=0.26)$. From Fig. $4 c$ it can be seen that emissions increased steadily until the early 2000s and thereafter remained approximately stable. The correlation between Spanish $\mathrm{NH}_{3}$ emissions and $\mathrm{NH}_{4}{ }^{+}$concentrations in bulk deposition was marginally significant ( $R=0.32 ; p=0.056)$, but the correlation increased when considering the Iberian Peninsula emissions $(R=0.36 ; p=0.027)$. No correlations were found between $\mathrm{NH}_{4}{ }^{+}$VWM concentrations in bulk deposition and Italian and France or the EU $28 \mathrm{NH}_{3}$ emissions, nor for $\mathrm{NH}_{4}{ }^{+}-\mathrm{N}$ fluxes and emissions of all the above considered countries.

Throughfall was sampled at two moments in this time series: the first (1995-1996) can be taken to represent the period of high $\mathrm{N}$ emissions. The more recent one (2011-1013) can be taken to represent the current situation, where $\mathrm{SO}_{2}$ and $\mathrm{NO}_{\mathrm{x}}$ emissions have been reduced but $\mathrm{NH}_{3}$ emissions still increase. Bulk deposition and throughfall VWM concentrations for these two periods are presented in Table 3. Non sea salt- $\mathrm{SO}_{4}{ }^{2-}$ concentrations in bulk deposition and throughfall declined between the two studied periods (with reductions of 63 and $60 \%$ for bulk deposition and throughfall, respectively). Changes in Spanish and the Iberian Peninsula $\mathrm{SO}_{2}$ emissions during this time span decreased by 72 and $76 \%$, respectively.

Nitrate concentrations decreased in bulk deposition between periods but increased by 23\% in throughfall (Table 3). Ammonium concentrations in bulk deposition and throughfall decreased between periods, with reductions of 46 and $72 \%$ for bulk deposition and throughfall (Table 3) while Spanish $\mathrm{NH}_{3}$ emissions increased by $8 \%$ in this period. Since atmospheric ammonia is principally involved in neutralizing $\mathrm{SO}_{2}$ to form ammonium sulfate aerosols, the strong decrease of $\mathrm{SO}_{2}$ may have resulted in a reduced formation of ammonium aerosols and may have facilitated $\mathrm{NH}_{3}$ dry deposition close to 
sources. However, the $\mathrm{N}$ changes in throughfall do not directly show the changes in dry deposition, since $\mathrm{N}$ can be taken up at the canopy level (Ignatova and Dambrine, 2000; Staelens et al., 2008). To deduce $\mathrm{N}$ dry deposition a canopy budget model was applied which is commented below.

\subsection{Dry deposition fluxes derived from a canopy budget model}

The methodology used here has been recommended in ICP-Forest manual even though some uncertainties remain for the estimation of $\mathrm{NO}_{3}{ }^{-} \mathrm{N}$ exchanges and dry deposition (Adriaenssens et al., 2012; Staelens et al., 2008). Since the assumptions included in the model were identical for the two study periods, results may be comparable between periods. Bulk and wet deposition were recalculated to coincide with the throughfall periods (Table 4).

The changes for the element fluxes in wet deposition for the years of throughfall data also indicated strong declines for $\mathrm{SO}_{4}{ }^{2-}-\mathrm{S}(59 \%), \mathrm{NH}_{4}{ }^{+}-\mathrm{N}(54 \%)$ and $\mathrm{NO}_{3}{ }^{-} \mathrm{N}(42 \%$, Table 4). However, based on the CBM estimations, dry deposition decreased for $\mathrm{SO}_{4}{ }^{2-}-\mathrm{S}(28 \%)$ and $\mathrm{NH}_{4}{ }^{+}-\mathrm{N}(5 \%)$ while it strongly increased for $\mathrm{NO}_{3}^{-}-\mathrm{N}$ from 1.26 to $6.76 \mathrm{~kg} \mathrm{NO}_{3}^{-}-\mathrm{N} \mathrm{ha}^{-1} \mathrm{y}^{-1}$ (Table 4). Thus, while in the first period, $\mathrm{NH}_{4}{ }^{+-} \mathrm{N}$ accounted for most of total inorganic $\mathrm{N}$ dry deposition (94\%), in the second it only accounted for $47 \%$. Changes in meteorology between periods may explain part of these differences, as discussed below.

\subsection{Changes in streamwater chemistry}

We hypothesized that the described changes in $\mathrm{N}$ atmospheric deposition will be transferred to the stream water, given the low residence time of water within this catchment which makes it highly responsive to inputs (Bernal et al., 2013). Streamwater $\mathrm{SO}_{4}{ }^{2-}$ concentrations decreased by $22 \%$ between an initial (1990-99) and a more recent period (2010-2014, Table 5), a lower decline than that of deposition that suggests soil sulphate retention. $\mathrm{NO}_{3}{ }^{-}$concentrations in streamwater more than doubled (significant to $\mathrm{p}<0.1$ ) but the change in $\mathrm{NO}_{3}{ }^{-} \mathrm{N}$ export was smaller due to the fact that fluxes result from the product of concentrations by water export which was lower in the second period. In Fig. 5, a clear change in the ecosystem response relative to $\mathrm{N}$ inputs is shown: 
436 for similar dissolved inorganic $\mathrm{N},\left(\mathrm{DIN}=\mathrm{NO}_{3}-\mathrm{N}+\mathrm{NH}_{4}-\mathrm{N}\right)$ deposition, higher exports were

437 found in the more recent period (2010-2014), suggesting the onset of $\mathrm{N}$ saturation.

438

439

440

441

442

443

444

445

446

447

\section{Discussion}

Large changes in the emission of acidifying pollutants have been achieved in Europe following the implementation of abatement measures in the 1980s. These measures are costly and there is an interest in contrasting their long-term effectiveness regarding changes in air quality, precipitation chemistry, atmospheric deposition and the response of ecosystems. However, the link between emissions, concentrations and deposition is complex and non-linearities between emission reductions and precipitation concentrations have been described (Fowler et al., 2005; 2007). Part of the lack of correlation may be due to the influence of meteorological conditions, which may impose a high variability to the rain chemistry and deposition series, especially in the Mediterranean because of its very high precipitation variability. However, long time series may reveal trends robust enough to describe the relationships between emissions and deposition. Here, we compared a simultaneous record of 30 years of emissions and precipitation chemistry and deposition at a site in NE Spain for a period encompassing marked changes in S and $\mathrm{N}$ emissions (Figs. 2 and 3).

In this study we observed similar declines in $\mathrm{SO}_{2}$ emissions in Spain (77\%) than in neighbouring countries and the EU28 (75-85\%, Table 3). However, the decline in $\mathrm{nsSSO}_{4}{ }^{2-}$ concentrations in precipitation and $\mathrm{SO}_{4}{ }^{2-}-\mathrm{S}$ deposition was lower (65\% and $62 \%$, respectively) than emissions. A similar pattern was found in a study of emission and deposition changes for 5 defined source regions in Europe for the period 1980-2000, in which the regions to which Spain belonged presented a $80 \%$ reduction in $\mathrm{SO}_{2}$ emissions and $40-50 \%$ reduction in $\mathrm{SO}_{4}{ }^{2}$-S deposition (Fowler et al., 2007).

For the period of common measures of wet deposition and throughfall, while $\mathrm{S}$ wet deposition decreased by $c a$. 60\%, the estimated change in dry deposition between 1995-96 and 2011-13 was only 28\% (Table 4), indicating a shift towards a higher contribution of dry deposition to total deposition (from 25 to 40\%) at this site as $\mathrm{SO}_{2}$ emissions are reduced. This may be explained by a drier meteorology in the second 
period ( $30 \%$ less precipitation) but is also consistent with an increase in the $\mathrm{SO}_{2}$ deposition velocity as ambient $\mathrm{SO}_{2}$ concentrations are reduced (Fowler et al., 2001).

When considering total deposition amounts (wet + dry), a $55 \%$ decline was found. This decline in $\mathrm{S}$ deposition can translate through soils to drainage waters. A previous study of small headwater streams in the Montseny mountains indicated a $30 \%$ decrease of $\mathrm{SO}_{4}{ }^{2-}$ concentration in streamwaters from 1980 to 2007 (Avila and Rodà, 2012). The results of the present work corroborate this trend by showing significant differences in streamwater $\mathrm{SO}_{4}{ }^{2-}$ concentrations in the $\mathrm{TMO}$ stream, and about half $\mathrm{S}$ exports from the catchment in the recent period (Table 5).

The emissions of oxidized $\mathrm{N}$ declined by $32 \%$ in Spain, a higher reduction than model estimates for the regions that include Spain in Fowler et al. (2007) which ranged between a small 2\% reduction and a 6\% increase. Overall, from 1983 to 2014, $\mathrm{NO}_{3}{ }^{-}$ concentrations in precipitation and $\mathrm{NO}_{3}{ }^{-}-\mathrm{N}$ deposition slightly increased (3-4\%). Nitrate concentrations in precipitation were explained $\left(R^{2}=0.92\right)$ by a model that included variations in precipitation amount, local $\mathrm{NO}_{\mathrm{x}}$ emissions in Barcelona, and emissions at a Peninsular scale. Spanish $\mathrm{NO}_{2}$ emissions from 1980 to 2013 showed a clear increasing trend until 2005 and a steep decline thereafter and $\mathrm{NO}_{3}{ }^{-}$concentrations closely tracked these changes (Fig. 3b). Main contributors to $\mathrm{NO}_{\mathrm{x}}$ emissions in Spain are road transport (33\%) and energy use + electricity supply for transport (60\%; EEA 2012). Electricity generation has shifted in recent years in Spain from coal and natural gas to a higher role of renewable energies. $\mathrm{NO}_{2}$ Spanish emissions closely tracked this change (linear correlation coefficient $r=0.94, p<0.001)$, suggesting the important role of electricity generation on $\mathrm{NO}_{x}$ emissions and eventually in $\mathrm{NO}_{3}{ }^{-}$deposition.

Ammonia emissions increased by 13\% in Spain between 1980 and 2012 (Table 2). However, $\mathrm{NH}_{4}{ }^{+}$in precipitation and $\mathrm{NH}_{4}{ }^{+} \mathrm{N}$ deposition at the Montseny site showed a decreasing trend (15\% reduction). This can be due to several processes and the interaction between them. Opposite time trends are involved in the formation of $\mathrm{NH}_{4}{ }^{+}$ aerosols (increasing $\mathrm{NH}_{3}$ and decreasing $\mathrm{SO}_{2}$ and $\mathrm{NOx}$ emissions): with declining $\mathrm{SO}_{2}$ and $\mathrm{NO}_{2}$ emissions in recent years there is a decreasing formation of ammonium sulphate and nitrate aerosols, thus lower $\mathrm{NH}_{4}{ }^{+}$is available to be scavenged by precipitation and 
lower $\mathrm{NH}_{4}{ }^{+}$in precipitation is expected. However, due to the reduced formation of aerosols, there are changes in the partitioning between $\mathrm{NH}_{3} / \mathrm{NH}_{4}{ }^{+}$and this may affect the residence time of $\mathrm{NH}_{4}{ }^{+}$in the atmosphere and thus the spatial scale of $\mathrm{NH}_{3} / \mathrm{NH}_{4}{ }^{+}$ deposition. Fine $\mathrm{NH}_{4}{ }^{+}$aerosols are long-range transported so that decreasing $\mathrm{SO}_{2}$ and $\mathrm{NO}_{\mathrm{x}}$ emissions will tend to decrease $\mathrm{NH}_{4}{ }^{+}$wet deposition at sites remote from sources, but enhance local dry deposition of $\mathrm{NH}_{3}$.

501

Dry deposition changes for $\mathrm{N}$ were estimated from throughfall measurements by applying a canopy budget model that indicated increasing $\mathrm{NO}_{3}-\mathrm{N}$ dry deposition (Table 4). A reason for this increase may be the very low initial throughfall $\mathrm{NO}_{3}-\mathrm{N}$ values in the year 1995-1996, a period that was 30\% rainier than usual, thus restraining the dry spells for dry deposition. As a further check of the validity of the $\mathrm{N}$ dry deposition estimates, we calculated dry deposition with the inferential method using a record of aerosol concentrations and gases $\left(\mathrm{HNO}_{3}, \mathrm{NO}_{2}, \mathrm{NH}_{3}\right)$ at the La Castanya plot and taking their deposition velocity $\left(V_{d}\right)$ from reported values for forests. This estimation was only done for the 2012 period because of lack of gas measurements in the 1995 period. The calculation produced a dry deposition estimate of $6.22 \mathrm{~kg} \mathrm{ha}^{-1} \mathrm{yr}^{-1}$ for $\mathrm{N}$-oxidized and $4.04 \mathrm{~kg} \mathrm{ha}{ }^{-1} \mathrm{yr}^{-1}$ of $\mathrm{N}$-reduced forms which compared well with the dry deposition estimate of $\mathrm{NO}_{3}^{-}-\mathrm{N}$ calculated with the $\mathrm{CBM}\left(6.76 \mathrm{~kg} \mathrm{ha}^{-1} \mathrm{yr}^{-1}\right)$ but underestimated $\mathrm{NH}_{4}{ }^{+}-\mathrm{N}$ deposition by $50 \%$. However, as a first approach, we can frame the dry deposition in 2011-2013 for $\mathrm{NO}_{3}^{-}-\mathrm{N}$ and $\mathrm{NH}_{4}{ }^{+} \mathrm{N}$ in 6-7 $\mathrm{kg} \mathrm{ha}^{-1} \mathrm{yr}^{-1}$ and 4-6 kg ha- $\mathrm{yr}^{-1}$, respectively. Total $\mathrm{N}$ deposition in both periods was similar (16-17 $\mathrm{kg} \mathrm{ha}^{-1} \mathrm{yr}^{-1}$, Table 4), but the contribution of the dry and wet modes varied between periods: while in 1995 dry and wet deposition fluxes were similar (around 50\%), in the recent period dry deposition dominated (75\%).

519 Chronic addition of $\mathrm{N}$ amounts in the range of $15-17 \mathrm{~kg} \mathrm{ha}^{-1} \mathrm{yr}^{-1}$ are within the critical loads proposed for Mediterranean sclerophyllous forests (15-17.5 $\mathrm{kgha}^{-1} \mathrm{yr}^{-1}$; (Bobbink et al., 2010). Thus, the holm oak forests in the NE Iberian Peninsula may be at the brink of experiencing adverse effects. One way to explore the $\mathrm{N}$ status of an ecosystem is to monitor the changes in the drainage waters of unperturbed catchments. At present, a shift is observed towards higher $\mathrm{N}$ export. 


\section{Conclusions}

526 Emissions of S in Spain, as in other European countries, have strongly decreased (77\%)

527 and that was reflected in reductions for $\mathrm{nsSSO}_{4}{ }^{2-}$ concentrations in precipitation and $528 \mathrm{SO}_{4}{ }^{2}$-S deposition (around 60\%) during the period from 1980 to 2012. The observed 529 lower decline (29\%) in dry deposition was consistent with reports of lower $\mathrm{SO}_{2}$ 530 deposition velocity as ambient $\mathrm{SO}_{2}$ is reduced.

$531 \mathrm{NO}_{2}$ emissions in Spain increased from 1980 to 1991, remained constant until 2005, and decreased thereafter, a pattern that was paralleled by $\mathrm{NO}_{3}{ }^{-}$in bulk precipitation at Montseny. This pattern seems to be related to a shift in electricity generation from coal and natural gas to a higher role of renewable energies in Spain. However, dry deposition increased markedly in the recent period, from 1.3 to $6.7 \mathrm{~kg} \mathrm{ha}^{-1} \mathrm{y}^{-1}$. Differences between the 2 periods were probably related to differences in rainfall amount, since the latter period was drier and the contribution from dry deposition was higher.

$\mathrm{NH}_{3}$ emissions have increased by a $13 \%$ between 1980 and 2014 in Spain but $\mathrm{NH}_{4}^{+}$ concentrations in precipitation and $\mathrm{NH}_{4}{ }^{+}-\mathrm{N}$ deposition at the Montseny site showed a decreasing trend (15\% reduction). We suggest that the reduction of $\mathrm{SO}_{2}$ and $\mathrm{NO}_{\mathrm{x}}$ emissions precludes the formation of ammonium sulphate and nitrate aerosols to be scavenged by rainfall. The estimations with a canopy budget model showed similar $\mathrm{NH}_{4}{ }^{+}-\mathrm{N}$ dry deposition between the compared periods.

544 The $\mathrm{N}$ loads at Montseny were in the range of $15-17 \mathrm{~kg} \mathrm{ha}^{-1} \mathrm{yr}^{-1}$, within the critical loads proposed for Mediterranean sclerophyllous forests (15-17.5 kg ha-1 $\mathrm{yr}^{-1}$; (Bobbink et al., 2010). The onset of $N$ saturation at this Mediterranean holm oak forests is suggested since higher DIN export during the more recent period sampled was registered under similar DIN loads.

\section{Acknowledgements}

551 The financial support from the Spanish Government projects CGL2009-13188-C03-01 552 and MONTES-Consolider CSD-2008-00040 is fully acknowledged. LA was supported by 553 the Ministry of Science and Innovation, Spanish Research Council (BES-2010-033274).

554 We thank an anonymous reviewer for suggestions on the manuscript. 
Aber J, McDowell W, Nadelhoffer K, Magill A, Berntson G, Kamakea M, et al. Nitrogen saturation in temperate forest ecosystems. BioScience 1998: 921-934.

Adriaenssens S, Staelens J, Wuyts K, Samson R, Verheyen K, Boeckx P. Retention of dissolved inorganic nitrogen by foliage and twigs of four temperate tree species. Ecosystems 2012; 15: 1093-1107.

Avila A. Time trends in the precipitation chemistry at a mountain site in northeastern Spain for the period 1983-1994. Atmospheric environment 1996; 30: 1363-1373.

Avila A, Rodà F. Assessing decadal changes in rainwater alkalinity at a rural Mediterranean site in the Montseny Mountains (NE Spain). Atmospheric environment 2002; 36: 2881-2890.

Avila A, Rodà F. Changes in atmospheric deposition and streamwater chemistry over 25years in undisturbed catchments in a Mediterranean mountain environment. Science of the Total Environment 2012; 434: 18-27.

Balestrini R, Arisci S, Brizzio MC, Mosello R, Rogora M, Tagliaferri A. Dry deposition of particles and canopy exchange: Comparison of wet, bulk and throughfall deposition at five forest sites in Italy. Atmospheric Environment 2007; 41: 745-756.

Bernal S, Belillas C, Ibáñez J, Àvila A. Exploring the long-term response of undisturbed Mediterranean catchments to changes in atmospheric inputs through time series analysis. Science of the Total Environment 2013; 458: 535-545.

Bobbink R, Hicks K, Galloway J, Spranger T, Alkemade R, Ashmore M, et al. Global assessment of nitrogen deposition effects on terrestrial plant diversity: a synthesis. Ecological applications 2010; 20: 30-59.

Boyce RL, Friedland AJ, Chamberlain CP, Poulson SR. Direct canopy nitrogen uptake from 15Nlabeled wet deposition by mature red spruce. Canadian Journal of Forest Research 1996; 26: 1539-1547.

Calvo A, Pont V, Olmo F, Castro A, Alados-Arboledas L, Vicente A, et al. Air masses and weather types: a useful tool for characterizing precipitation chemistry and wet deposition. Aerosol and Air Quality Research 2012; 12: 856-878.

De Vries W, Vel E, Reinds G, Deelstra H, Klap J, Leeters E, et al. Intensive monitoring of forest ecosystems in Europe: 1. Objectives, set-up and evaluation strategy. Forest Ecology and Management 2003; 174: 77-95.

Draaijers G, Erisman J. A canopy budget model to assess atmospheric deposition from throughfall measurements. Water, Air, and Soil Pollution 1995; 85: 2253-2258.

Drever JI. The geochemistry of natural waters. 126-128. Prentice-Hall, Inc., Englewood Cliffs. N. Jersey, 1982.

Driscoll C, Likens G, Church M. Recovery of surface waters in the northeastern US from decreases in atmospheric deposition of sulfur. Water, Air, and Soil Pollution 1998; 105 : 319-329.

EC. Directive 2001/81/EC, OJ L 309, 22-30, 27 November, 2001.

EEA. Air Quality in Europe-2012 Report. 2012

Erisman J, Mennen M, Fowler D, Flechard C, Spindler G, Grüner A, et al. Deposition monitoring in Europe. Environmental Monitoring and Assessment 1998; 53: 279-295.

Escudero M, Querol X, Avila A, Cuevas E. Origin of the exceedances of the European daily PM limit value in regional background areas of Spain. Atmospheric Environment 2007; 41: 730-744.

Evans C, Reynolds B, Hinton C, Hughes S, Norris D, Grant S, et al. Effects of decreasing acid deposition and climate change on acid extremes in an upland stream. Hydrology and Earth System Sciences Discussions Discussions 2007; 4: 2901-2944. 
Fagerli $\mathrm{H}$, Aas W. Trends of nitrogen in air and precipitation: Model results and observations at EMEP sites in Europe, 1980-2003. Environmental Pollution 2008; 154: 448-461.

Fowler D, Smith R, Muller J, Cape JN, Sutton M, Erisman JW, et al. Long term trends in sulphur and nitrogen deposition in Europe and the cause of non-linearities. Water, Air, \& Soil Pollution: Focus 2007; 7: 41-47.

Fowler D, Smith R, Muller J, Hayman G, Vincent K. Changes in the atmospheric deposition of acidifying compounds in the UK between 1986 and 2001. Environmental Pollution 2005; 137: $15-25$.

Fowler D, Sutton M, Flechard C, Cape J, Storeton-West R, Coyle M, et al. The control of SO2 dry deposition on to natural surfaces by $\mathrm{NH} 3$ and its effects on regional deposition. Water, Air and Soil Pollution: Focus 2001; 1: 39-48.

Gilbert RO. Statistical Methods for Environmental Pollution Monitoring 1987. Van Nostrand Reinhold. New York.

Grennfelt $P, \operatorname{Hov} \varnothing$. Regional air pollution at a turning point. AMBIO: A Journal of the Human Environment 2005; 34: 2-10.

Hereter A, Sánchez JR. Experimental areas of Prades and Montseny. Ecology of Mediterranean evergreen oak forests. Springer, 1999, pp. 15-27.

Ignatova N, Dambrine É. Canopy uptake of N deposition in spruce (Picea abies L. Karst) stands. Annals of forest science 2000; 57: 113-120.

Izquierdo R, Alarcón M, Aguillaume L, Avila A. Effects of teleconnection patterns on the atmospheric routes, precipitation and deposition amounts in the north-eastern Iberian Peninsula. Atmospheric Environment 2014; 89: 482-490.

Izquierdo R, Benítez-Nelson CR, Masqué P, Castillo $S$, Alastuey A, Àvila A. Atmospheric phosphorus deposition in a near-coastal rural site in the NE Iberian Peninsula and its role in marine productivity. Atmospheric Environment 2012; 49: 361-370.

Konovalov I, Beekmann M, Burrows J, Richter A. Satellite measurement based estimates of decadal changes in European nitrogen oxides emissions. Atmospheric Chemistry and Physics 2008; 8: 2623-2641.

Lindberg S, Lovett G. Deposition and forest canopy interactions of airborne sulfur: results from the integrated forest study. Atmospheric Environment. Part A. General Topics 1992; 26: 1477-1492.

Llorens P, Domingo F. Rainfall partitioning by vegetation under Mediterranean conditions. A review of studies in Europe. Journal of Hydrology 2007; 335: 37-54.

Lovett G, Lindberg S. Dry deposition and canopy exchange in a mixed oak forest as determined by analysis of throughfall. Journal of Applied Ecology 1984: 1013-1027.

Lövblad G, Tarrasón L, Tørseth K, Dutchak S. emeP assessment Part i: european Perspective. Norwegian Meteorological Institute, PO Box 2004; 43.

Manual ICP-Forest. Manual on methods and criteria for harmonized sampling, assessment, monitoring and analysis of the effects of air pollution on forests. UN-ECE, Fed. Res. Centre for Forestry and Forest Products (BFH) 1998.

Mosello R, Bianchi M, Geiss H, Marchetto A, Morselli L, Muntau H, et al. Italian Network for the Chemistry of Atmospheric Deposition. Intercomparison 1/98. Consiglio Nazionale delle Ricerche. Istituto Italiano di Idrobiologia. Verbania Pallanza. 81 pp, 1998.

Parker G. Throughfall and stemflow in the forest nutrient cycle. Advances in ecological research 1983; 13: 57-133.

Prado-Fiedler R. On the relationship between precipitation amount and wet deposition of nitrate and ammonium. Atmospheric Environment. Part A. General Topics 1990; 24: 3061-3065.

Pérez N, Pey J, Castillo S, Viana M, Alastuey A, Querol X. Interpretation of the variability of levels of regional background aerosols in the Western Mediterranean. Science of the total environment 2008; 407: 527-540. 
Rekolainen S, Posch M, Kämäri J, Ekholm P. Evaluation of the accuracy and precision of annual phosphorus load estimates from two agricultural basins in Finland. Journal of Hydrology 1991; 128: 237-255.

Reuss J, Johnson D. Ecological studies 59. Springer-Verlag, New York, 1986.

Rodrigo A, Avila A, Roda F. The chemistry of precipitation, throughfall and stemflow in two holm oak (Quercus ilex L.) forests under a contrasted pollution environment in NE Spain. Science of the Total Environment 2003; 305: 195-205.

Rodà F, Retana J, Gracia CA, Bellot J Ecology of Mediterranean evergreen oak forests. Vol 37: Springer Publ, 1999.

Schaefer DA, Reiners WA. Throughfall chemistry and canopy processing mechanisms. Acidic precipitation. Springer, 1990, pp. 241-284.

Schmitt M, Thöni L, Waldner $P$, Thimonier A. Total deposition of nitrogen on Swiss long-term forest ecosystem research (LWF) plots: comparison of the throughfall and the inferential method. Atmospheric Environment 2005; 39: 1079-1091.

Skjelkvåle B, Stoddard J, Jeffries D, Tørseth K, Høgåsen T, Bowman J, et al. Regional scale evidence for improvements in surface water chemistry 1990-2001. Environmental Pollution 2005; 137: 165-176.

Staelens J, Houle D, De Schrijver A, Neirynck J, Verheyen K. Calculating dry deposition and canopy exchange with the canopy budget model: review of assumptions and application to two deciduous forests. Water, Air, and Soil Pollution 2008; 191: 149-169.

Stone K, Hunt P, Novak J, Johnson M, Watts D. Flow-proportional, time-composited, and grab sample estimation of nitrogen export from an eastern Coastal Plain watershed. Transactions of the ASAE 2000; 43: 281-290.

Swistock BR, Edwards PJ, Wood F, Dewalle DR. Comparison of methods for calculating annual solute exports from six forested Appalachian watersheds. Hydrological Processes 1997; 11: 655-669.

Thimonier A, Schmitt, Waldner P, Rihm B. Atmospheric deposition on Swiss long-term forest ecosystem research (LWF) plots. Environmental Monitoring and Assessment 2004; 30: 138.

Tørseth K, Aas W, Breivik K, Fjæraa A, Fiebig M, Hjellbrekke A, et al. Introduction to the European Monitoring and Evaluation Programme (EMEP) and observed atmospheric composition change during 1972-2009. Atmospheric Chemistry and Physics 2012; 12: 5447-5481.

Ulrich B. Interaction of forest canopies with atmospheric constituents: SO2, alkali and earth alkali cations and chloride. Effects of accumulation of air pollutants in forest ecosystems. Springer, 1983, pp. 33-45.

UNECE. Protocols to the Convention on Long-Range Transboundary Air Pollution 2011,, http://www.unece.org/env//rtap/status/Irtap s.htm [accessed 8 May 2011]. 2011.

van Jaarsveld BC, Krijnen P, Pieterman H, Derkx FH, Deinum J, Postma CT, et al. The effect of balloon angioplasty on hypertension in atherosclerotic renal-artery stenosis. New England Journal of Medicine 2000; 342: 1007-1014.

Zhang G, Zeng GM, Jiang YM, Yao JM, Huang GH, Jiang XY, Tan W, Zhang XL, Zeng M. Effects of weak acids on canopy leaching and uptake precesses in a coniferous-decideous mixed evergreen forest in central-south China. Water, Air and Soil Pollution 2006; 172: 39-55. 
704

\begin{tabular}{ccc}
$1995-96$ & $1995-96$ & $2011-13$ \\
LC1 & RP1 & LC2 \\
& & \\
731 & 535 & 765 \\
$\mathrm{~N}$ & $\mathrm{SW}$ & $\mathrm{SW}$ \\
$11.3 \pm 4.8$ & $12.0 \pm 4.2$ & $13.0 \pm 4.1$ \\
2127 & 1753 & 2571 \\
26.5 & 22.3 & 29.0 \\
\hline
\end{tabular}

705

Altitude (m)

Orientation

Diameter at breast high $(\mathrm{cm})$

Trees.ha ${ }^{-1}$

Basal area $\left(\mathrm{m}^{-2}\right)$

706

707

708

709

710

711

712

713

714

715

716

717

718

719

720 
Table 2. Emission trends for Spain and surrounding countries between 1980 and 2012 726 (Portugal, between 1992 and 2012). Negative percent change indicates reduction and 727 positive percent, increase between 5-yr initial and final periods. Man-Kendall $p$ value is 728 also indicated.

\begin{tabular}{|c|c|c|c|c|c|c|c|}
\hline & & $\begin{array}{l}\text { Mann- } \\
\text { Kendall } \\
\text { p value }\end{array}$ & $\begin{array}{c}\text { 5-year } \\
\text { initial } \\
\text { Gg }\end{array}$ & & $\begin{array}{c}\text { 5-year } \\
\text { final } \\
\text { Gg }\end{array}$ & & \\
\hline Emission & & & Mean & SD & Mean & SD & \%change \\
\hline \multirow[t]{5}{*}{$\mathrm{SO}_{2}$} & Portugal & $<0.0001$ & 305 & 31 & 48 & 5 & -84 \\
\hline & Spain & $<0.0001$ & 1870 & 233 & 430 & 26 & -77 \\
\hline & France & $<0.0001$ & 1004 & 220 & 255 & 29 & -75 \\
\hline & Italy & $<0.0001$ & 1302 & 262 & 195 & 18 & -85 \\
\hline & Iberian P. & $<0.0002$ & 2175 & 249 & 479 & 28 & -78 \\
\hline \multirow[t]{5}{*}{$\mathrm{NO}_{2}$} & Portugal & 0.003 & 257 & 7 & 170 & 8 & -34 \\
\hline & Spain & 0.265 & 1391 & 28 & 942 & 19 & -32 \\
\hline & France & $<0.0001$ & 1746 & 107 & 1017 & 44 & -42 \\
\hline & Italy & $<0.0001$ & 1863 & 201 & 904 & 53 & -51 \\
\hline & Iberian P. & 0.245 & 1648 & 31 & 1112 & 26 & -33 \\
\hline \multirow[t]{5}{*}{$\mathrm{NH}_{3}$} & Portugal & $<0.0001$ & 61 & 2 & 47 & 1 & -22 \\
\hline & Spain & $<0.0001$ & 339 & 26 & 384 & 6 & 13 \\
\hline & France & 0.049 & 688 & 9 & 697 & 22 & 1 \\
\hline & Italy & $<0.0001$ & 455 & 10 & 388 & 14 & -15 \\
\hline & Iberian P. & $<0.0001$ & 339 & 25 & 437 & 7 & 8 \\
\hline
\end{tabular}


739 Table 3. Water volume $\left(\mathrm{mm} \mathrm{y}^{-1}\right)$ and ion VWM concentrations (in ueq $\left.\mathrm{L}^{-1}\right)$ in bulk

740 deposition (BD) and throughfall (TF) and their percent change between an initial (6 June

7411995 to 25 June 1996) and final period (1 March 2011 to 1 March 2013) at Montseny.

742 Negative percent change indicates reduction and positive percent, increase, between

743 the two periods.

744

745

\section{Water}

vol. $\quad \mathrm{pH}^{1} \quad \mathrm{H} \quad$ Alk $\quad \mathrm{Na}^{+} \quad \mathrm{K}^{+} \quad \mathrm{Ca}^{2+} \quad \mathrm{Mg}^{2+} \quad \mathrm{NH}_{4}^{+} \quad \mathrm{NO}_{3}^{-} \quad \mathrm{SO}_{4}{ }^{2-} \mathrm{nssSO}_{4}{ }^{2-} \quad \mathrm{Cl}^{-}$

\section{5-1996}

BD

1161.5

5.28

$8.7 \quad 19.1$

$\begin{array}{llll}21 & 3.78 & 36.9 & 7.88\end{array}$

$\begin{array}{llll}32.7 & 29.5 & 41.1 & 38.6\end{array}$

26.6

TF

858.5

$\begin{array}{lll}6.11 & 1.25 & 76.2\end{array}$

$\begin{array}{llll}32 & 64.1 & 79.5 & 26.2\end{array}$

$\begin{array}{llll}41.9 & 33.6 & 71.2 & 67.4\end{array}$

55.5

\section{1-2013}

BD

860

$6.06 \quad 1.9$

41.5

$\begin{array}{lll}20.3 & 3.2 & 53.3\end{array}$

11.1

17.6

18

$\begin{array}{lll}16.6 & 14.2 \quad 21.2\end{array}$

TF

694

5.931.

75.7

$\begin{array}{lll}44.4 & 60.8 & 108\end{array}$

43

11.8

41.3

$32 \quad 26.7$

63.7

\begin{tabular}{cccccccccccccc}
\hline $\begin{array}{c}\text { \%change } \\
\text { BD }\end{array}$ & -26.0 & 14.8 & 78.2 & 117.3 & -3.3 & -15.3 & 44.4 & 40.9 & -46.2 & -39.0 & -59.6 & -63.3 & -20.3
\end{tabular}

\%change

$\begin{array}{llllllllllllll}\text { TF } & -19.2 & -2.9 & 12.0 & -0.7 & 38.8 & -5.1 & 35.8 & 64.1 & -71.8 & 22.9 & -55.1 & -60.4 & 14.8\end{array}$

\section{$746{ }^{1}$ Median $\mathrm{pH}$}

747

748

749 
754

755

756 Table 4. Fluxes in wet deposition (WD), net throughfall (nTF) and Total deposition (TD).

757 Dry deposition (DD) and canopy exchange (CE) fluxes have been derived from a

758 throughfall canopy budget model for an initial (1995-1996) and a recent period (2011-

759 2013). Units in $\mathrm{kg} \mathrm{ha}^{-1} \mathrm{y}^{-1}$.

\begin{tabular}{cccccccccc}
\hline & $\mathrm{Na}^{+}$ & $\mathrm{K}^{+}$ & $\mathrm{Ca}^{2+}$ & $\mathrm{Mg}^{2+}$ & $\mathrm{NH}_{4}{ }^{+}-\mathrm{N}$ & $\mathrm{NO}_{3}{ }^{-}-\mathrm{N}$ & sum N & $\mathrm{SO}_{4}{ }^{2-}-\mathrm{S}$ & $\mathrm{Cl}^{-}$ \\
\hline 1995-1996 & & & & & & & & & \\
WD & 4.10 & 1.13 & 6.29 & 0.74 & 5.13 & 3.51 & 8.64 & 6.17 & 7.23 \\
nTF & 2.08 & 19.5 & 7.11 & 1.95 & -0.29 & 0.37 & 0.08 & 3.37 & 9.27 \\
DD & 2.08 & 0.58 & 3.12 & 0.37 & 6.36 & 1.26 & 7.62 & 2.31 & 3.75 \\
CE & 0.00 & 18.9 & 3.99 & 1.58 & -6.65 & -0.89 & -7.54 & 0.59 & 5.52 \\
TD & 6.18 & 1.72 & 9.41 & 1.11 & 11.5 & 4.77 & 16.3 & 9.34 & 11.0 \\
\hline 2011-2013 & & & & & & & & & \\
WD & 4.59 & 0.98 & 9.78 & 1.17 & 2.36 & 2.03 & 4.39 & 2.52 & 6.44 \\
nTF & 3.02 & 18.4 & 8.02 & 3.10 & -1.04 & 2.60 & 1.56 & 1.53 & 11.5 \\
DD & 3.02 & 0.65 & 6.40 & 0.77 & 6.07 & 6.76 & 12.8 & 1.66 & 4.24 \\
CE & 0.00 & 17.8 & 1.58 & 2.33 & -7.12 & -4.16 & -11.3 & -0.13 & 7.23 \\
TD & 7.61 & 1.63 & 16.2 & 1.94 & 8.43 & 8.79 & 17.2 & 4.18 & 10.7 \\
\hline & & & & & & & & & \\
WD \%change & 12.0 & -13.3 & 55.5 & 58.1 & -54.0 & -42.2 & -49.2 & -59.2 & -10.9 \\
DD \%change & 45.2 & 12.1 & 105.1 & 108.1 & -4.6 & 436.5 & 68.4 & -28.1 & 13.1 \\
TD \%change & 23.1 & -5.2 & 72.4 & 74.8 & -26.7 & 84.3 & 5.8 & -55.2 & -2.7 \\
\hline 760 & & & & & & & & &
\end{tabular}

761

762

763

764 
765 Table 5. Comparison of stream conductivity, ion VWM concentrations (in $\mu$ eq $\mathrm{L}^{-1}$ ), water

766 drainage $\left(\mathrm{mm} \mathrm{v}^{-1}\right)$ and fluxes in streamwater (in $\mathrm{kg} \mathrm{ha}^{-1} \mathrm{y}^{-1}$ ) from the TMO catchment.

767 Differences between periods were tested with ANOVA (initial period=1990-1994. recent

768 period $=2010-2014$ ) and significant differences are highlighted in bold. Percent

769 differences between periods are also indicated.

770

\begin{tabular}{ccccccccccc}
\hline & Water & Cond. & Alk & $\mathrm{Na}^{+}$ & $\mathrm{K}^{+}$ & $\mathrm{Ca}^{2+}$ & $\mathrm{Mg}^{2+}$ & $\mathrm{NO}_{3}^{-}$ & $\mathrm{SO}_{4}{ }^{2-}$ & $\mathrm{Cl}^{-}$ \\
\hline VWM & & & & & & & & & & \\
1990-1999 & - & $\mathbf{5 3 . 6}$ & $\mathbf{2 9 1}$ & 197 & 8.2 & $\mathbf{2 0 3}$ & 192 & 4.5 & $\mathbf{1 5 7}$ & 90.7 \\
$\begin{array}{c}\text { 2010-2014 } \\
\text { p-value }\end{array}$ & - & $\mathbf{6 3 . 7}$ & $\mathbf{3 8 3}$ & 219 & 7.2 & $\mathbf{2 5 3}$ & 145 & 11.2 & $\mathbf{1 2 3}$ & 95.4 \\
\%change & & $\mathbf{0 . 0 0 1}$ & $\mathbf{0 . 0 1 2}$ & 0.053 & 0.36 & $\mathbf{0 . 0 0 2}$ & 0.064 & 0.081 & $\mathbf{0 . 0 0 5}$ & 0.47 \\
& & 19 & 32 & 11 & -12 & 25 & -24 & 250 & -22 & 5 \\
Export flux & & & & & & & & & & \\
& & & & & & & & $\mathrm{NO}_{3}^{-} \mathrm{N}$ & $\mathrm{SO}_{4}^{-} \mathrm{S}$ & \\
1990-1999 & 403 & & 1105 & 17.7 & 1.29 & 15.9 & 6.1 & 0.33 & 10.1 & 12.9 \\
2010-2014 & 283 & & 1043 & 14 & 0.84 & 14.4 & 4.9 & 0.49 & 5.65 & 9.6 \\
p-value & 0.35 & & 0.83 & 0.47 & 0.3 & 0.68 & 0.47 & 0.55 & 0.15 & 0.4 \\
\%change & -30 & & -6 & -21 & -35 & -9 & -20 & 48 & -44 & -26 \\
\hline
\end{tabular}

771

772

773

774

775

776

777

778

779

780

781 
783 Fig. 1 Study site at La Castanya (Montseny mountains, NE Spain). LC1 corresponds to 784 1983-2000 bulk deposition and 1995-1996 throughfall measurements. LC2 corresponds 785 to 2002-2014 bulk deposition and 2011-2013 throughfall measurements. The Torrent 786 de la Mina catchment (TMO) is also indicated.

787 Fig 2. Precipitation and drainage from the Torrent de la Mina stream for the period 788 1983-2014. Units are $\mathrm{mm} \mathrm{y}^{-1}$. Hydrologic years defined from 1 September.

789 Fig 3. Temporal evolution of emissions reported to EMEP (in Gg) for Spain and 790 neighbouring countries. a) $\mathrm{SO}_{2}$, b) $\mathrm{NO}_{2}$, c) $\mathrm{NH}_{3}$.

791 Fig 4. Temporal evolution of annual VWM concentrations in bulk deposition at la

792 Castanya (Montseny)and annual Spanish emissions. a) $\mathrm{SO}_{4}$ mean concentrations in bulk 793 deposition and $\mathrm{SO}_{2}$ emissions, b) $\mathrm{NO}_{3}$ mean concentrations in bulk deposition and $\mathrm{NO}_{2}$ 794 emissions, c) $\mathrm{NH}_{4}$ mean concentrations in bulk deposition and $\mathrm{NH}_{3}$ emissions.

795 Fig 5. Dissolved inorganic nitrogen (DIN $=\mathrm{NO3}-\mathrm{N}+\mathrm{NH} 4-\mathrm{N})$ annual fluxes in the 796 streamwaters draining the TMO catchment $v$ s. annual DIN bulk deposition fluxes at the 797 site, for two recording periods.

798

799

800

801

802

803

804

805

806

807

808

809

810 
$812 \quad$ Fig 1

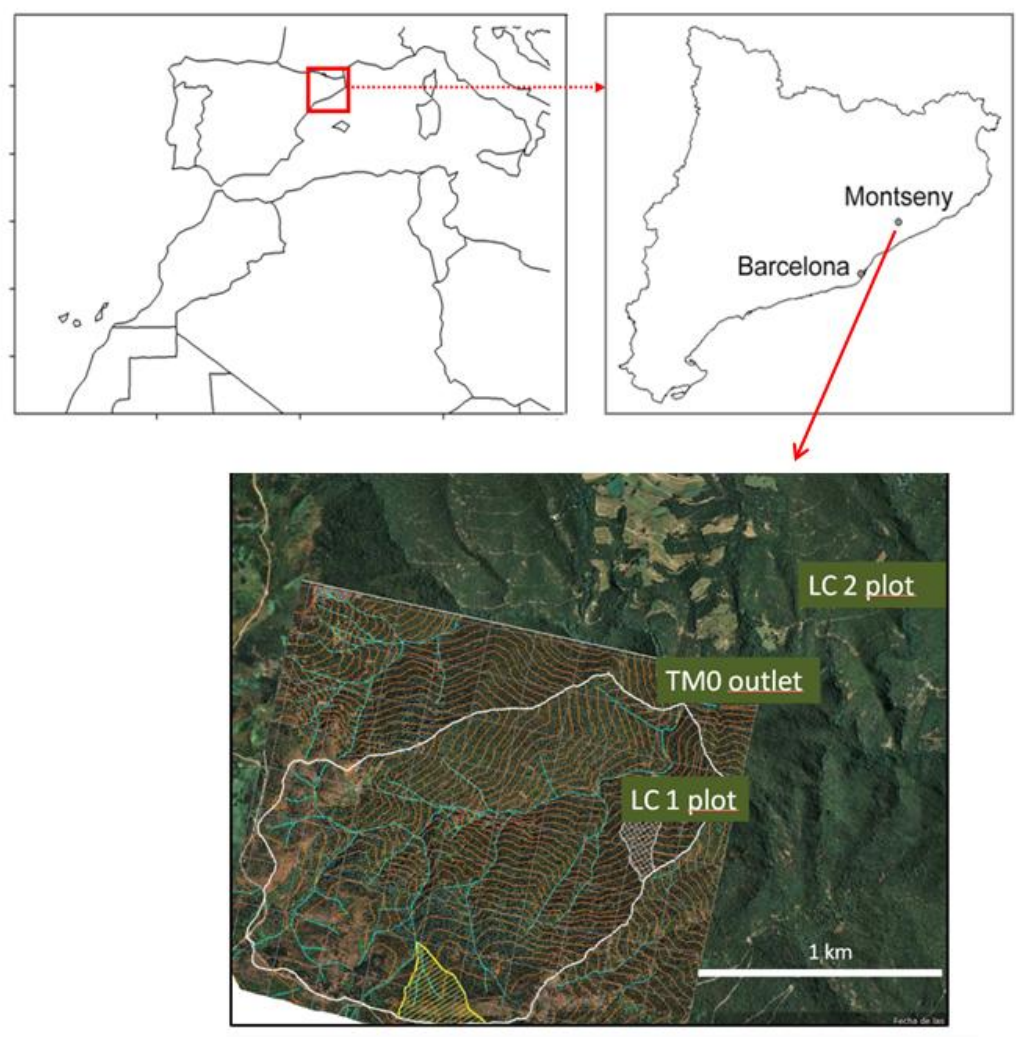

813

814

815

816

817

818

819

820

821

822

823 
Fig 2

825

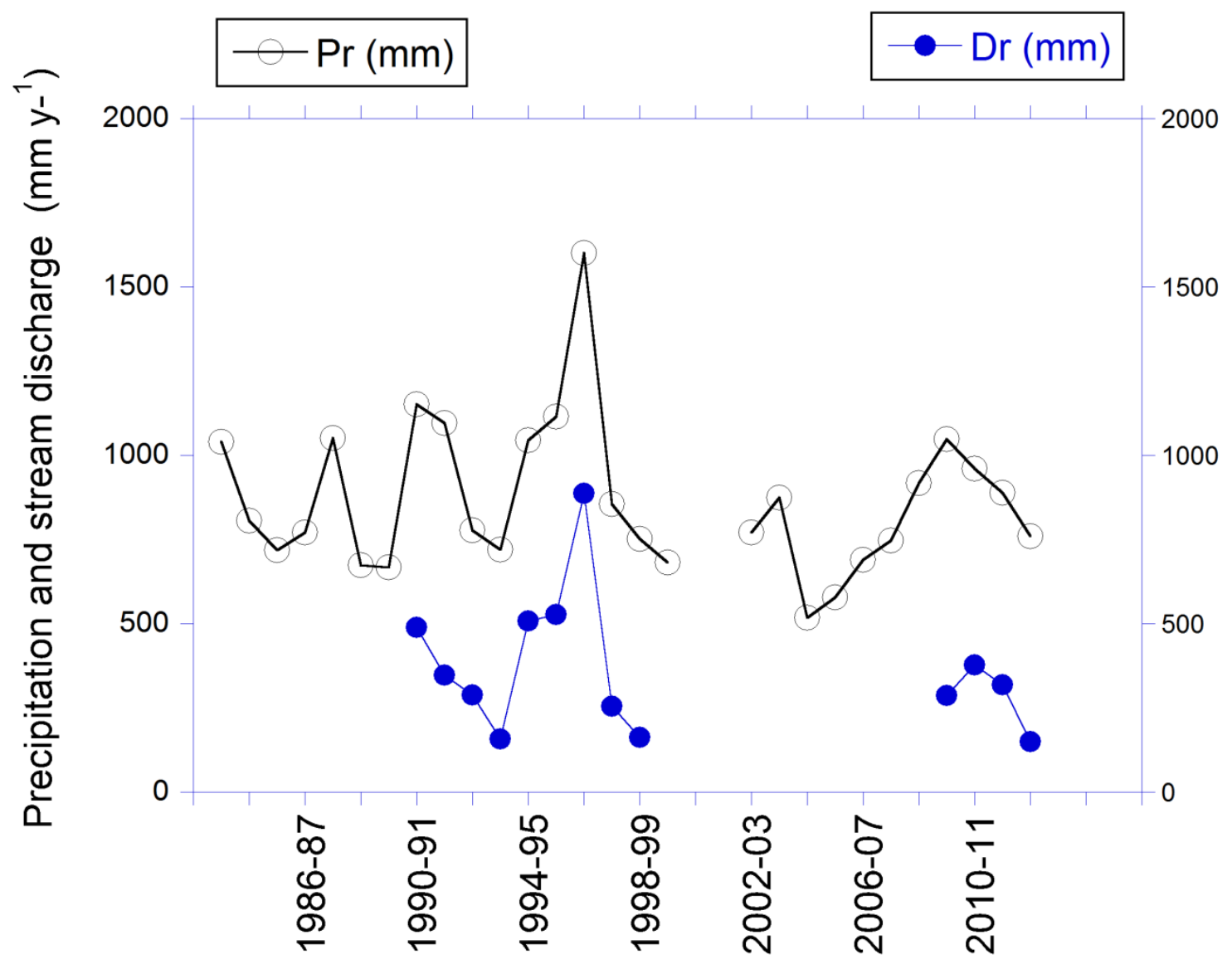

826

827

828

829

830

831

832

833

834 
a)

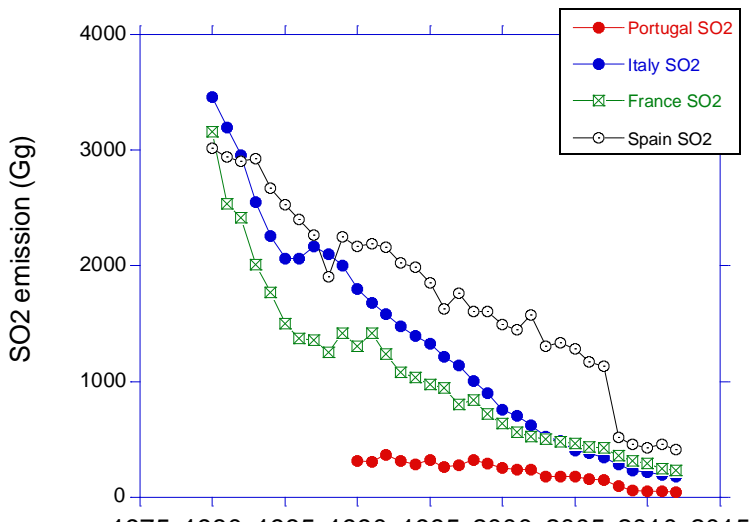

197519801985199019952000200520102015

b)

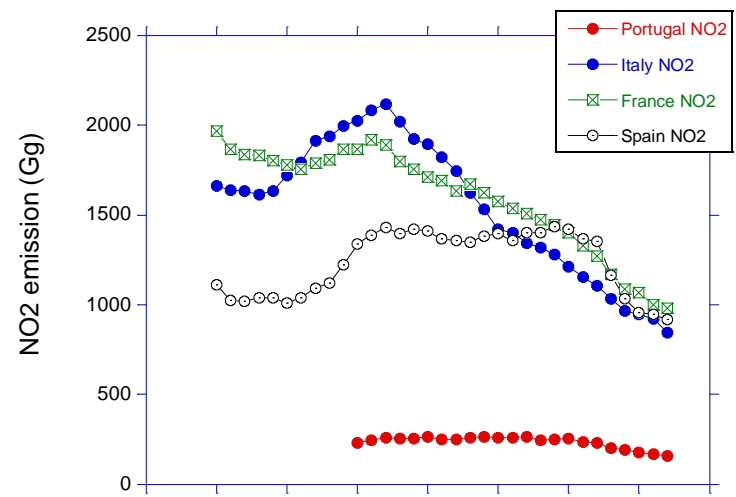

197519801985199019952000200520102015

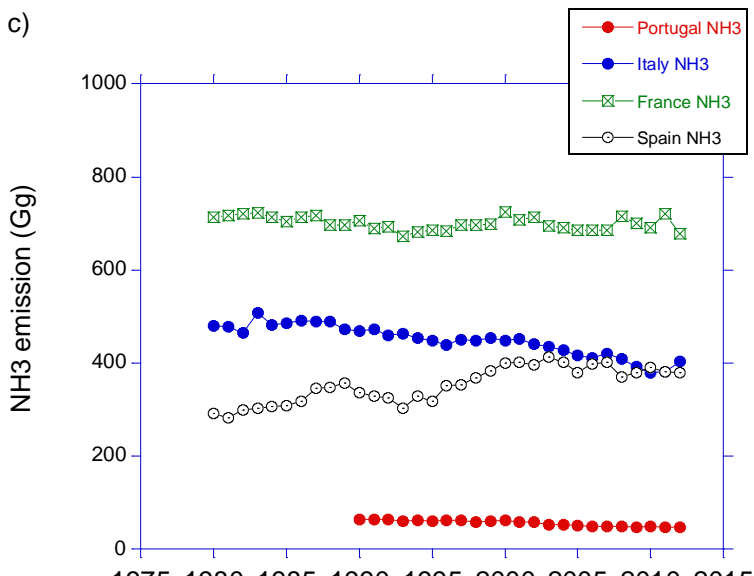

197519801985199019952000200520102015 
a)

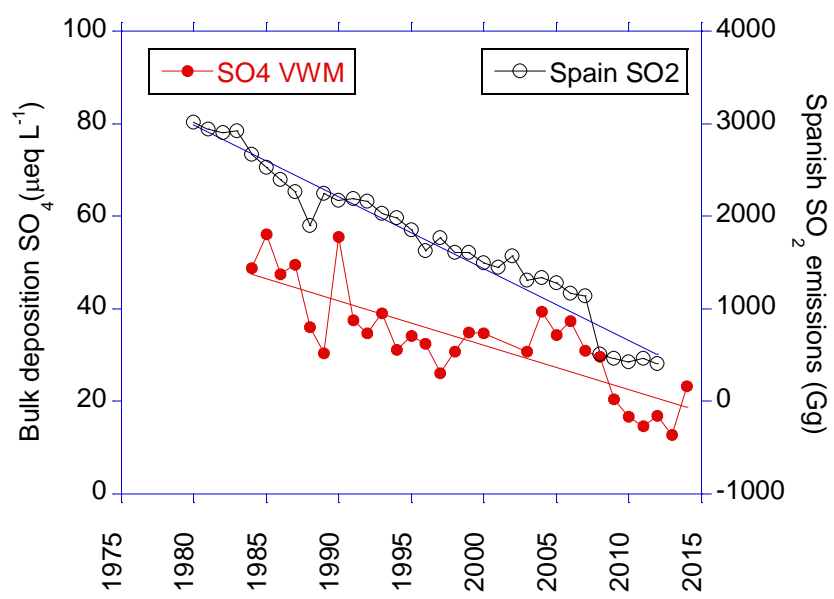

b)

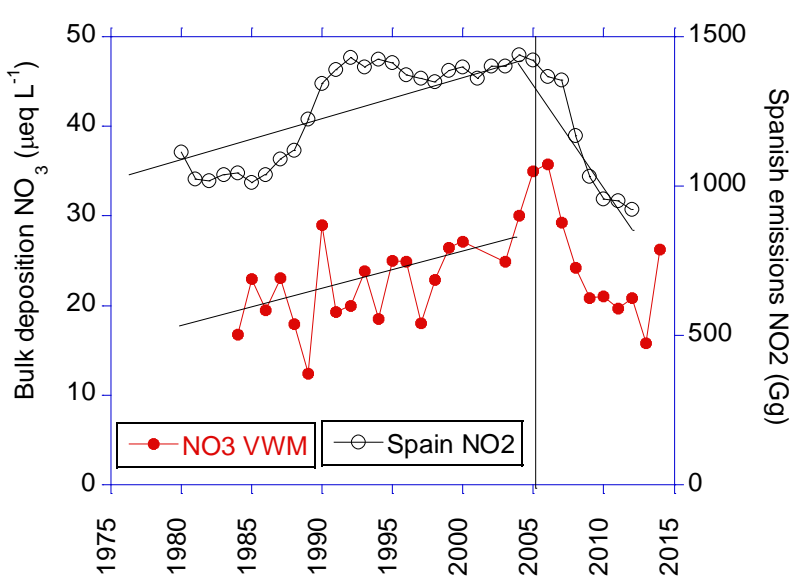

c)

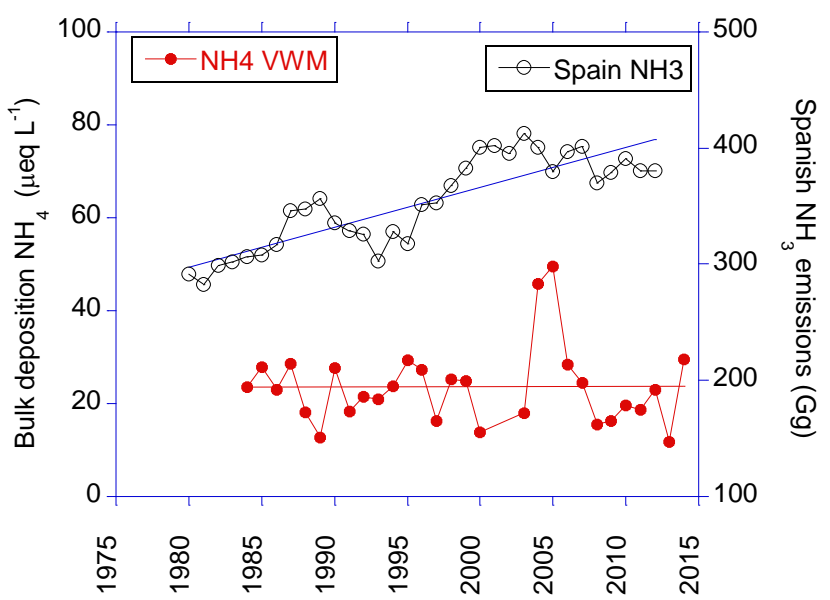


$842 \quad$ Fig 5

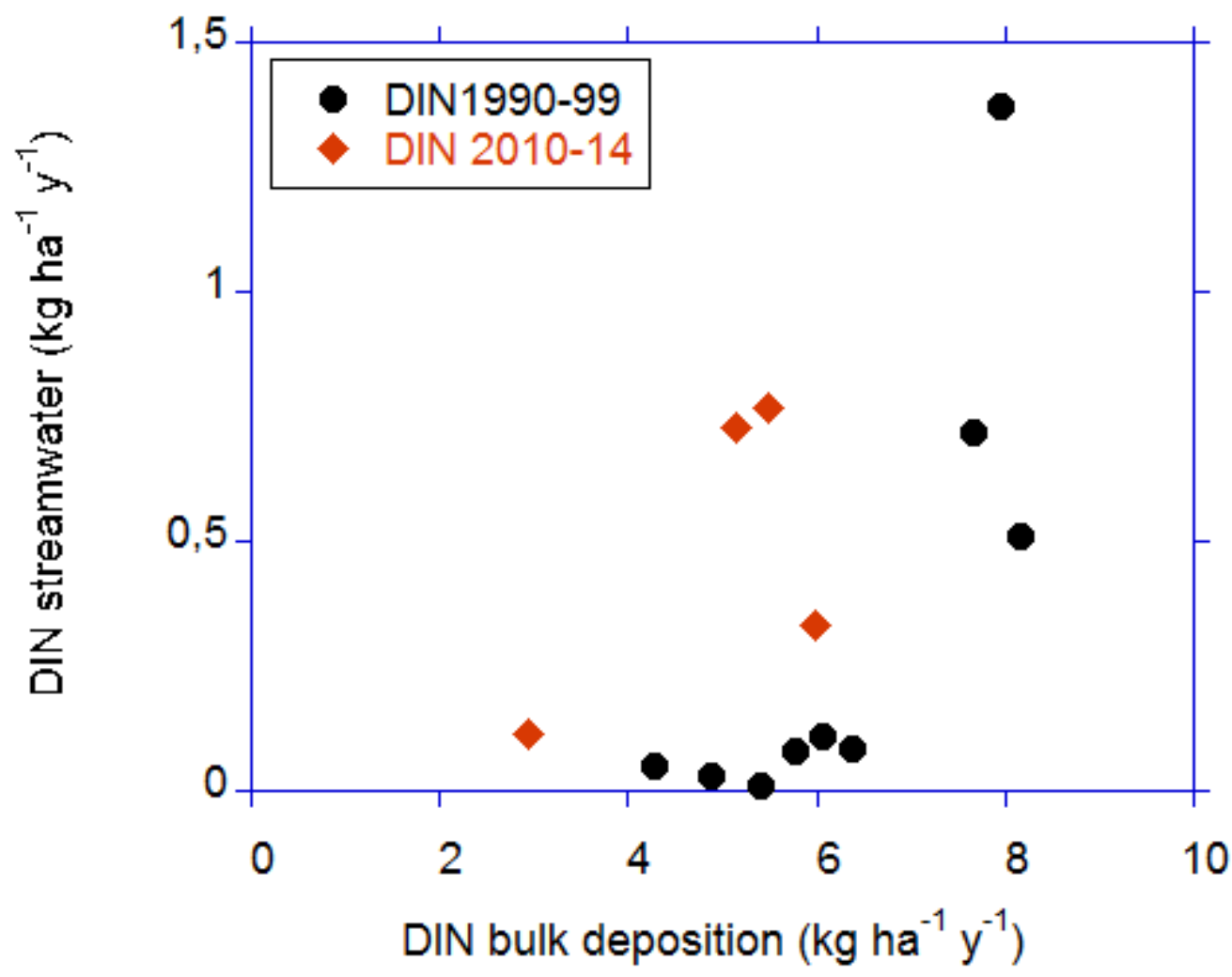

843 